\title{
TELEKI KÁLMÁNNÉ KIRÁLYFÖLDI ANTÓNIA 65. SZÜLETÉSNAPJÁRA
}

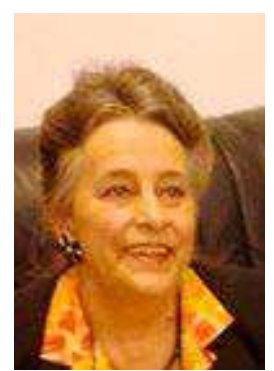

Teleki Kálmánné Királyföldi Antónia 1953ban született Budapesten, építőmérnök szülök gyermekeként.

Müszaki tanulmányait 1968-ban a Kvassay Jenő Híd- Vízmüépítő Technikumban kezdte, majd - mint számos kollégája, a Ratkó-korszaknak köszönhetően - 1974ben a Közlekedési és Távközlési Müszaki Főiskolán hídépítő és fenntartó üzemmérnöki oklevelet szerzett.

Építésvezetői munka mellett a Budapesti Müszaki Egyetem Szakirányos Üzemmérnök Továbbképző szakán lett okleveles szerkezetépítő mérnök 1979-ben. Építéstechnológiai szakmérnöki vörösdiplomáját 1983-ban kapta.

Szakmai érdeklődése, nagyrészt a kiskörei vízlépcső építésénél eltöltött termelési gyakorlatnak köszönhetően, a kivitelezés felé fordult. A Vízügyi Építő Vállalatnál volt munkakezdő, ahol művezetőként, majd építésvezetőként több vízépítési mütárgy kivitelezésénél vállalt aktív szerepet, mint például: a szentendrei regionális vízellátás monolit vasbeton ivóvíztároló ikermedencéi, Esztergom monolit vasbeton szennyvíz-főgyüjtője és átemelö telepe dunai kitorkoló müvel, Észak-pesti szennyvíztisztító telep nagymütárgyai, daruzott vasbeton ipari csarnokok.

1981 és 1990 között az Út- és Vasútépítő Vállalat termeléselökészítő mérnöke volt. Része volt a Székesfehérvári Könynyüfémmü csarnokainak rekonstrukciójában és bőví6tésében, honvédségi, mezőgazdasági, bányászati, ipari és technológiai létesítmények (közúti és vasúti rakodók, hidak, silók, támfalak, acél és vasbeton ipari csarnokok, térburkolatok, távvezetékek, városi közmüvek) megvalósításában.

1985 és 1990 között vállalati gazdasági munkaközösségben híd- és mütárgytervezési tevékenységet folytatott Tatabánya térségében.

Az Út- és Vasútépítő Vállalat 1990. évi csődje miatt a Betonútépítő Vállalatnál, majd jogutódjánál, a Betonútépítő Nemzetközi Építőipari Rt-nél alkalmazták. A központi vállalkozási osztályon, majd a szerkezetépítési igazgatóságon hídépítési fötanácsos, tervezési csoportvezetői beosztásban közremüködhetett az alábbi mütárgyak létesítésének versenyajánlatának kidolgozásában, szükség szerint alternatív tervezésben, technológiai javaslatok és utasítások összeállításával (a teljesség igénye nélkül). Az M0, M1, M3, M5, M7 és M15 autópályák hídjai, a francia koncesszióban megnyert, de akkor meg nem valósított $\mathrm{S} 9$ gyorsforgalmi út és a „szekszárdi” Duna-híd, számtalan országos és önkormányzati út építendő új, illetve felújítandó hídjai, a millenniumi kisföldalatti és az Andrássy út rekonstrukciója, a megvalósításra váró DélBuda-Rákospalota metróvonal felszíni mütárgyai, a nagymarosi tájrehabilitáció, a Lágymányosi Duna-hídnak és kapcsolódó létesítményei, a Ferihegyi repülőtér II. terminál bővítésée, a budapesti Nagykörúti villamosvágány-cserer, a Petőfi-híd, a dunaföldvári Duna-híd és az Esztergom-štúrovói Mária Valéria híd felújítása, a szegedi Belvárosi és Felsővárosi, a cigándi, záhonyi és tiszaugi Tisza-hidak, a budapesti Gubacsi úti, Baross téri, Jászberényi úti, Kacsóh Pongrác úti és Ferdinánd felüljárók felújítása, a szlovén vasúti kapcsolat magyar, illetve szlovén oldali mútárgyai

Munkáltatója révén FIDIC alapú nemzetközi pályázatok elkészítésében is tevékeny részem volt: IFOR Bosznia, Románia, Lengyelország, Szlovénia, Horvátország autópálya-programjai, Olaszország és Izrael területén vasúti és magasépítési projektek.

A cég tevékenységi körének bővítése kapcsán, külföldi meg- rendelők megbízására a Mátrai, a Paksi és az Újpesti Erőmü bővítési-átépítési pályázatában is közremüködött.

A Betonútépítő Nemzetközi Építőipari Rt. megbízásából 1994ben-együttmüködve a francia koncessziós partnerrel és a generál tervező Uvatervvel elkészítette a fent említett $\mathrm{S} 9$ gyorsforgalmi út (ma M9) 11 hídjának engedélyezési tervdokumentációját.

Müszaki igazgatói megbízásra - a cég szabad kapacitása biztosítása érdekében - tanulmánytervet készített utólag, illetve újonnan létesíthető, eltolódás ellen mikrocölöp-sorra telepített, rúdláncként müködő, géplánccal folyamatosan építhető, gyorsan javítható monolit vasbeton terelőelemre, továbbá pályaburkolat nélküli, primer korrózióálló feszített vasbeton autópálya alul- és felüljáróra. Ezek az elképzelések akkoriban piaci okok miatt nem nyertek életteret.

2000 novemberétől - a Betonútépítő Nemzetközi Építőipari Rt. csődje miatt - a Központi Közlekedési Felügyelet Közúti Felügyelet, Hídügyi Önálló Csoportjában vezető fótanácsosi munkakört töltött be. 2007. júliusáig mintegy ezernégyszáz híd építésiengedélyezési, kiviteli terv jóváhagyási és forgalomba helyezési ügye tartozott hozzá, fóként az M7 autópálya Budapestországhatár és az M0 útgyürü M5 és 2. föút közötti szakaszán, a Széchenyi Plusz programban, az Európai Unió által támogatott önkormányzati fejlesztésekben, illetve az országos közúthálózat 30 m össznyílás-hosszt meghaladó hídjai esetében. Említésre méltó volt az M1 autópálya és a 2/A foút vasalt talajtámfalas hídfőinek helyreállítása, a hazai gyakorlatban először létesített ,extradosed bridge" az M7-M70 autópálya-csomópontban (Korongi híd), az M0 útgyürü beton pályaburkolatú felülójárói (negyven éve épült az utolsó), a nagyszilárdságú, nagyteljesítményü feszített felszerkezetü, pályaburkolattal nem rendelkező S65 jelü híd az M7 autópálya felett, a megépült ,,kosárfülü” ívhíd Salgótarjánban.

2007 júliusában az ugrásszerűen megnövekedett feladatok miatt megalakult a Közúti Főosztályon belül a Hídügyi Osztály, melynek vezetésére kinevezést kapott. Azóta évente 600-1200 hídépítési tárgyú hatósági döntés született, beleértve a megépült autópályák és autóutak hídjait, az uniós támogatással épült különleges önkormányzati gyalogos- és kerékpáros hidakat (például a szolnoki Tiszavirág-híd) is. Vezetői beosztása mellett saját ügye volt a Kőröshegyi, a Pentele, a Megyeri hidak forgalomba helyezésének engedélyezése, az M0 útgyürü kéttámaszú, 56 m nyílású kísérleti alumínium gyaloghídja, az M43 autópálya kísérleti Móra Ferenc hídjának és az M0 új Hárosi- és Soroksári Duna-hídja, a budapesti Szabadság, Margit és a Széchenyi Lánchíd és alagút felújításának teljes engedélyezése. Külön említést érdemel az M0 útgyürü keleti szakaszán megépült betonpályás hidak hatósági kezelése, illetve a precedens-értékü négy alagútpár az M6 autópályán, az összes tervezési, hibás kivételezési és alagút-biztonsági extrákkal.

A fib Magyar Tagozatának titkára volt 2000 januárjától 2007-ig.

2010-ben a győri Jedlik Ányos híd megvalósítása hatósági tevékenységéért emlékérmet kapott, 2011. március 15-én a nemzeti fejlesztési miniszter Közlekedési Érdeméremmel tüntette ki. Szakmai elismerésként 2014-ben a hidász szakmától mint tiszteletbeli „hídkezelő” Apáthy-emlékérmet kapott.

A közszolgálati törvény alapján két éve nyugdíjas. Kívánjuk, hogy örizze sokáig fiatalos lendületét, munkakedvét. Mindehhez kívánunk jó egészséget és örömteli magánéletet.

B. L. Gy. 


\section{DR.-HABIL. GÁLOS MIKLÓS 80. SZÜLETÉSNAPJÁRA}

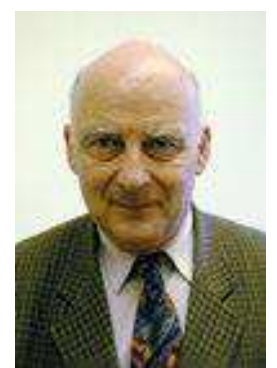

Dr.-habil. Gálos Miklós egyetemi tanár 1938-ban született Budapesten. 1956-ban érettségizett a Budapest XX. ker. Kossuth Lajos Gimnáziumban.

Egyetemi tanulmányait 1961-ben fejezte be az Építöipari és Közlekedési Müszaki Egyetem Mérnöki Karán. Acélszerkezeti szakmérnöki oklevelét 1967ben szerezte meg a BME Építőmérnöki Karán. 1971-ben a Müegyetemen müszaki doktori, 1992-ben a Magyar Tudományos Akadémián kőzetek szilárdsági tulajdonságaival foglalkozó disszertációjának megvédése után a müszaki tudományok kandidátusa fokozatot nyerte el. 1998-ban habilitált. 1961 és 1963 között kivitelező mérnökként a Györi Vagon és Gépgyár hídgyáregységében dolgozott, majd 1963 és 1978 között a vegyi- és a kőolajipar tervező intézeteiben több nagylétesítmény megvalósításában irányító tervezőként vett részt. 1978 óta a BME Építőanyagok és Magasépítés Tanszékén - különböző megnevezésü jogelőd tanszékein (Ásvány- és Földtani Tanszék, Mérnökgeológiai Tanszék, Építőanyagok és Mérnökgeológia Tanszékén) tudományos fömunkatársként, egyetemi docensként, majd egyetemi tanárként oktatott és kutatott nyugdíjba vonulásáig.

Egyetemi tanárként a Tanszéken a Mérnökgeológiai tanszéki csoport, valamint a Tanszék Anyagvizsgáló laboratóriumának kőzetvizsgáló laborrészleg vezetőjeként tevékenykedett.
Nyugdíjas egyetemi tanárként is részt vesz mind az oktatási, mind a kutatási munkában, ápolva ipari kapcsolatait. Oktatási és kutatási tevékenységét a kőzetmechanika, a teherviselő kőszerkezetek, az építési kőanyagok minősítése, valamint a mélyépítés mérnökgeológiája különböző szakterületein fejti ki. Több pályázatban témavezetőként és kutató munkatársként vett részt. Kutatási munkájának eredményeit több 100 publikációban, hazai és nemzetközi konferencia kiadványokban, könyv és könyvrészletekben tette közkinccsé.

Müszaki közéleti tevékenysége szerteágazó. Elnöke a Szilikátipari Tudományos Egyesület Kö- és kavics szakosztályának, több cikluson keresztül elnöke volt a Magyarhoni Földtani Társulat Mérnökgeológiai és Környezetföldtani szakosztályának. Tagja az ISSMR, az ICOMOS és a fib Magyar Tagozatának.

Munkája elismeréseként két alkalommal kapott Miniszteri Emlékplakettet, továbbá az elmúlt években Miniszteri dicséretben és Miniszteri elismerő oklevél kitüntetésben részesült. Tulajdonosa a Szilikátiparért éremnek és az Ipar Müszakifejlesztésért Alapítvány II. díjának. Oktatási munkájának elismeréseként rektori dicséret kitüntetést

kapott és két alkalommal vehette át a TDK Munkáért Emlékplakettet.

Jubiláris születésnapja alkalmából értékes tevékenységében további számos sikert, magánéletében sok örömöt, mindehhez tartós, jó egészséget kívánunk

L. E.

\section{LAKATOS ERVIN 85. SZÜLETÉSNAPJÁRA}

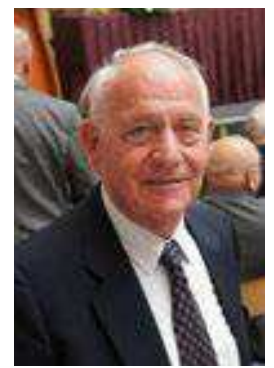

Lakatos Ervin, Állami-díjas 1933-ban született Budapesten.

1956-ban a KÉV-Metró Vállalatnál mint müszaki vezető kezdte pályafutását, majd építésvezető, fó-építésvezető, fömérnök volt a budapesti metróépítés különböző szakaszain. 1981-ben kinevezték a Hídépítő Vállalat igazgatójának, majd vezérigazgatójának. Végrehajtotta a vállalat teljes körű átszervezését, építési tevékenységének bővítését. 1991-1992-ben megszervezte a Ballast Nedam holland építőipari cég magyarországi igazgatóságát, és ennek igazgatójaként előkészítette a tervezett 1996-os Budapesti Világkiállítás konzulensi szerződéseit. 1993-1994-ben létrehozta az Expo'96 Kft-t, vezérigazgatójaként a Világkiállítás lemondásáig irányította a felkészülést.

1994 és 1999 között a Strabag Hungária Építő Rt. vezérigazgatója volt. 2003-ig a Magyar Hídépítő Konzorcium projektvezetőjeként irányította a szekszárdi Duna-híd építését. 2003-ban a 4-es Metró. 2003-ban a 4-es Metró Projektvezető Tanácsadó
Testületének tagja volt. 2004-ben a 2-es metró felújításakor független mérnöki tevékenységet folytatott.

Számos külföldi megbízásnak tett eleget. Alagútépítést irányított Calcuttában, Belgrádban, Dortmundban. Szakmai eredményeit különböző mélyépítési tudományos folyóiratokban, mélyalapozási és alagútépítési tanulmányokban tette közzé.

Tagja volt a KTE Mélyalapozási Szakosztálya Vezetőségének, a Nemzetközi Feszítettbeton Bizottságnak, alelnöke az Építőipari Vállalkozói Szövetségnek és a fib Magyar Tagozatának.

Munkássága elismeréseként a budapesti metróépítésért Állami-díjat kapott. Elnyerte a Magyar Köztársaság Csillagrendjének ezüst fokozatát, az Eötvös Loránd-díjat és a Lechner Ödön-díjat.

Az BME Szenátusa gyémántdiploma adományozásával ismerte el értékes mérnöki tevékenységét (2006).

A fib Magyar Tagozat nevében kívánunk jó egészséget és hosszú életet.

B. L. Gy. 